This item was submitted to Loughborough's Research Repository by the author.

Items in Figshare are protected by copyright, with all rights reserved, unless otherwise indicated.

\title{
Is leagile still relevant? A review and research opportunities
}

\section{PLEASE CITE THE PUBLISHED VERSION}

https://doi.org/10.1080/14783363.2020.1750360

\section{PUBLISHER}

Taylor \& Francis (Routledge)

\section{VERSION}

AM (Accepted Manuscript)

\section{PUBLISHER STATEMENT}

This is an Accepted Manuscript of an article published by Taylor \& Francis in Total Quality Management and Business Excellence on 20 April 2020, available online: http://www.tandfonline.com/10.1080/14783363.2020.1750360.

\section{LICENCE}

CC BY-NC-ND 4.0

\section{REPOSITORY RECORD}

Bhamra, Ran, Alka Nand, Lili Yang, Paula Albregard, Glaucia Azevedo, Daniella Corriaini, and Maria Emiliasiq. 2020. "Is Leagile Still Relevant? A Review and Research Opportunities". Loughborough University. https://hdl.handle.net/2134/12034863.v1. 


\title{
Is Leagile still relevant? A Review and Research Opportunities
}

\begin{abstract}
Leagile is an approach to managing production and supply chain excellence that is a hybrid of conventional Lean and Agile thinking and methods. This paper reviews the extant literature relating to Leagile and in the process identifies important opportunities for advancing research. Although several review works exist for lean operations (e.g. Jasti \& Kodali, 2015), this paper seeks to be the first to specifically review Leagile research. Following review of recent, literature reviews (Ho et al, 2015; Jasti \& Kodali, 2015), a seven-step process was developed to undertake this research. A total of 225 articles were reviewed, resulting in 53 articles where Leagile was a central theme. Findings include and reveal that Leagile is recognised as important for business excellence (Aykuz, 2014) but under-investigated; papers in high quality publications have declined to date; $73 \%$ of research articles used qualitative research methods. Research that involves practical studies comparing the paradigms lean, agile and leagile, tends to better understand the difficulties and better implementation practices of the theme. The service, SME and health sectors are particularly fitting for further work given their competitive, progressive and relatively unexplored nature.
\end{abstract}

\section{Keywords:}

Leagile, Quality Excellence, Lean, Agile, Review 


\section{Introduction}

Katayama \& Bennett (1999) noted that dramatic changes in the business environment caused by market instability, technological development and globalisation are affecting manufacturing companies, this is still the case today. Companies no longer compete between companies, instead it is their supply chain arrangements that determines their successes or failures (Christopher \& Towill, 2001), and companies must match their operations with customer needs and in order to accomplish this goal, managers must learn to recognise the most adequate strategies (Hallgren \& Olhager, 2009; Lemieux et al, 2015). The concept of lean manufacturing that is synonymous with the Toyota Production System, has clearly been a key driver in this ongoing change (Krishnamurthy \& Yauch, 2007). The lean strategy advocates optimisation of process flow and encourages the full use of workers' capabilities. The principles focus on the reduction of cost by assuming that the company should have only the essential quantity of production supplies along with building up a system that will offer an opportunity for workers to develop their full abilities (Sugimori et al., 1977). An ability to quickly reconfigure aspects of one's operations later became an important competitive factor. Here, 'Agility' in manufacturing systems is flexibility (Christopher \& Towill, 2001) and enables organisations to grow in a competitive market of unexpected changes and give a rapid response to fluctuating markets driven by customer-based evaluation of services and products (Yusuf et al., 1999).

A hybrid approach that some companies have adopted is the combination of both lean and agile strategies, a total supply chain perspective commonly referred to as 'leagile' (Naylor et al., 1999). The main difference between the two approaches in terms of customer value is that lean targets Muda (wastes) and uninterrupted flow that is central to sales prices, whereas agility focuses on flexibility and speed which are central to customer service (Aitken et al., 2002). Despite the differences, the connection between the two strategies can be extremely beneficial for organisations, particularly in terms of total quality excellence (Akyuz, 2014). Lean allows companies to target much smoother demand and reduced variety leading to cost reductions while agility enables focus on a highly variable demand, product variety, and the capability of delivering to an unpredictable marketplace (MasonJones et al., 2000b).

According to Naim \& Gosling (2011), there is a need to research a generic definition of Leagile, its characteristics and attributes. Although recent reviews have looked at Lean (Jasti \& Kodali, 2015), Leagile supply chain risk (Ahmed \& Huma, 2018), Lean performance (Negrao et at, 2017) and Lean healthcare (Costa \& Filho, 2016), to date, a Leagile review has not directly been addressed. This paper therefore provides a full and systematic review of Leagile. This paper seeks to understand the current state of research into Leagile systems and provide insights as to future research directions.

To explore these research questions in depth, the paper is set out as follows: introduction followed by a background on lean, agile and leagile approaches is presented. Section three details the research methodology adopted, and section four presents the results of extant literature on the key themes. Section five presents discussion, conclusions and directions for future research.

\section{Background}

\subsection{Lean}

The term lean manufacturing was first mentioned in the book 'The Machine That Changed the World', (Womack et al, 1990) when the authors reported findings from their study of the Toyota 
Production System. The lean concept has a clear focus on the reduction and elimination of waste (Ohno, 1988). Ohno, a former vice-president of Toyota implemented changes and created the basic just-in-time framework in the company, so it could compete following World War II. Lamming (1996) has since expanded the use of this term from manufacturing firms to supply chain management and to encompass other industries.

The lean methodology puts emphasis on zero waste or 'Muda' in Japanese. Ohno identified seven categories of waste (overproduction, waiting, transportation or conveyance, over processing or incorrect processing, excess inventory, unnecessary movements and defects) and suggested ways to avoid them. According to Womack \& Jones (1996), lean thinking supports organisations in "specifying value, line up value creating actions in the best sequence, conduct these activities without interruption whenever someone requests them, and perform them more and more effectively". Lean advocates that companies use more efficient human effort, equipment, time and space while offering the client what they want and what the customer considers as value.

One of the most important aspects of lean thinking is the definition of value, determined by the client's perception and how much he is willing to pay for it. Thereafter, everything that does not add value in the buyer's' point of view is considered as waste (Bicheno \& Holweg, 2004). Considering these features, it is possible to assume that the application of lean is best utilized in markets where demand is relatively stable and predictable, with a low variety and high volume (Christopher, 2000).

\subsection{Agile}

Agile manufacturing, a conceptual approach for more flexible manufacturing and supply chain operations. This flexible and high-quality way to produce goods includes both manufacturer and customer. The concept of agile manufacturing involves the ability to deal with changes by the application of partners' capabilities to supply customised products. It calls for the synthesis of numerous technologies within an integrated system (Jin-Hai et al., 2003). Agility can also be defined as the skill of businesses to grow in a competitive market of incessant and unanticipated change and being able to respond quickly to fast changing markets driven by customer-based evaluation of products and services (Yusuf et al., 1999).

Agile manufacturing is a broad, strategic, market driven approach that involves taking a balanced consideration of organisation, people and technology in a more integrative way. It is not only driven by technology, although it plays an important role. The objective of agile manufacturing is to create an environment that exercises human skills, judgment, creativity and knowledge and employs the best use of modern computer-based technologies (Kidd, 1994).

\subsection{Leagile}

The combined strategy of lean manufacturing upstream and agile response downstream is commonly referred to as leagile. According to Naylor et al. (1999): "Agility means using market knowledge and a virtual corporation to exploit profitable opportunities in a volatile market place" and "leanness means developing a value stream to eliminate all waste, including time, and to ensure a level schedule"

As noted, lean promotes smooth demand, reduced variety, and decreasing costs, while the agile part enables highly variable demand, product variety, and the capability of delivering to an unpredictable marketplace (Mason-Jones et al., 2000b). This combination therefore allows companies 
to manufacture products in a generic format for as long as possible and then just assemble them once an order or request has been received from the final consumer (Chan et al., 2009).

Christopher \& Towill (2001) present three approaches for combining lean and agile to form leagile strategies: these being the decoupling point approach, Pareto approach, and separation of 'base' and 'surge' demands. The latter approach separates the base demand, managed with lean procedures, from surge demand, managed with an agile strategy. Here, Pareto analysis is often used and separates products by volume, shows where the top 20 per cent of products are more predictable and could be managed with lean, whilst the remaining 80 per cent being less predictable, could be managed with an agile strategy. In the former approach, a decoupling point aims to use the lean paradigm up to a certain point within the supply chain, and then to employ an agility strategy in the remaining downstream segment. These strategies can be combined dependent upon the exact context and market requirements.

The profit source in each approach is different. Agile takes advantage of the volatility of the marketplace, while lean benefits from the reduction and elimination of non-value adding activities. The distinction can be analysed in terms of market qualifiers and market winners. Quality and leadtime are prerequisites to compete in the market for both methods, however, service level in agile will be the one to win the customer order, and the cost will be the definitive factor in the lean supply (Mason-Jones et al., 2000a). The main goal of this strategy is to place the decoupling point as near as possible to the end user, so the lead time can be minimized (Chan et al., 2009), Table 1 summarises the distinguishing attributes for lean, agile and leagile.

\section{Take in}

Table 1: Lean, agile and leagile attributes (Agarwal et al., 2006)

From Table 1, a combination of lean and agile features strategies generates leagile attributes. Lean precedes agile both geographically and temporally. Regarding material flow, the supply chain starts with leanness and then changes to agility. This same idea is used when it comes to formulating a company strategy, start applying lean thinking and then adapt to agile by removing limitations and constraints (Mason-Jones et al., 2000b).

\section{Research methodology}

The primary objective of this article is to review the published scientific literature on the subject leagile systems, within the operations management research field. Therefore, it is descriptive in relation to the purpose of research (Yin, 2003; Robson, 2002). The research conducted in this paper is via literature review, simultaneously organising existing primary publications and explicitly exposing the means used and the results obtained (Pai et al., 2004). The literature review provides support for the identification of a research topic, constructing the theoretical knowledge, promoting the analysis and the interpretation of the results (Rowley \& Slack, 2004). A mixed method approach is undertaken meaning the combination of qualitative and quantitative approaches, since it required both subjective and objective treatment (Creswell, 2003). 
Following review of recent, previous literature review articles (Ho et al, 2015; Jasti \& Kodali, 2015), a seven-step process was developed to undertake this research. The review process steps are as follows: (i) database selection, (ii) keywords' selection, (iii) search for documents, (iv) removal of repetitive articles, (v) first elimination of texts, (vi) second elimination of texts, and (vii) review of selected texts.

\subsection{Search protocol}

Any articles published up to the end of 2017 were reviewed. The research was conducted as follows: (i)The first action was to select a set of academic databases: Emerald Insight, Scopus, Web of Science, Science Direct and the Loughborough University Library database were used. (ii) The keywords for the search were defined and both the terms 'leagile' and 'leagility' were used in the search with each of the databases. (iii) The searches were conducted in ways to achieve capture of all relevant peer-reviewed publications. Keywords used were sought in the title, abstract and keywords. Publication in any year was allowed. Table 2 below shows the outcome of the initial search.

Take in

Table 2: Raw outcome of the initial search

These filtering criteria yielded a total of 225 publications. (iv) Following the initial collection of documents, it was necessary to remove any recurring articles. This process was conducted in two stages: firstly, the removal of repetitive texts under each search term, resulting in 78 leagile and 34 leagility articles; then secondly, the exclusion in between the terms, resulting in 88 papers. (v) The selected texts were analysed for relevance in the study, i.e., articles that investigate the theme or apply its concepts, resulting in a final number of 53 studies. (vi) Each article was fully reviewed, classified and tabulated as part of the results.

The construction of the database took into consideration the research question of the article that sought to understand how leagile / leagility has been addressed in scientific studies. The study was divided into two parts, publication related, and contents related. The first classification, publication related, contains the following subtopics: availability, methodology, year and journals. This first part analyses the relevant literature on leagile and demonstrates its usage and coverage to date. The second classification is content focused and explores the development of the theme and uses the following subtopics: concepts, leagile vs leagility, terms, theme, small and medium-sized enterprises and sector. This second part attempts to explore the leagile theme itself from various works and viewpoints

\section{Results}

This literature review aims to compile information regarding a specific subject field in a manner that identify and organize the state of the art (Rowley \& Slack, 2004).

\subsection{Publication related}


This section addresses all the articles published related to leagile/leagility, it analyses the availability, the methodology used in each paper, the years that they were published and the journals in which they are available.

\subsubsection{Availability}

Table 3 separates the articles that specifically discuss leagile or leagility. The division was made by separating the papers that were considered relevant for the study and those that were irrelevant.

Take in

Table 3: Relevant articles

The papers were separated into two categories: Relevant and Irrelevant. The Relevant (51 articles) are the ones that have pertinent information and discussion on leagile whether exploring the subject, conducting a case study or a literature review. Beyond that, they present important information about methodology, approach, purpose of research and unit of analysis. Alternatively, the Irrelevant articles (37 papers) are classified as such due to two reasons: if researchers merely cite leagile, use leagile as a superficial example or references an article about the subject but the paper itself does not study the subject, or they do not provide in-depth information about the variables that are important to leagile.

With the aim of classifying the papers, Table 4 was organised following the categorisation format used by Bhamra et al. (2011). It presents the classification of all the papers, 53 in total, considered relevant to the study. The articles were classified according to their methodology, theoretical approach, purpose of research and unit of analysis.

Take in

Table 4: Methodology, approach, purpose and unit of analysis in leagile literature

The information in Table 4 above is summarized in Table 5 below.

Take in

Table 5: Summary of Methodology, approach, purpose and unit of analysis in leagile literature (\% of 53 articles) 
Table 5 identifies the percentage number of articles contributing to the major areas of research methods, approach, purpose and unit of analysis. The totals do not add up to $100 \%$ for each major area as each individual article may contribute one or more of them.

Case study is a research strategy that can be used to provide description, test or generate theory, focusing in the dynamics of examples (Eisenhardt, 1989), and appears in 57\% of the studies. Theory building helps understand how a phenomenon occurs and to construct its concepts and interrelationships (Corley \& Gioia, 2011), is observed in 55\% of the studies. Model and framework development, is where a model is used to represent or explain a specific mechanism and framework is used to display any empirical relationships between various features under study, occur in $45 \%$ of the papers. Survey, that is the systematic collection of data, in the form of face interviews, telephone interviews or mail questionnaires (Mathiyazhagan \& Nandan, 2010), only arose in $8 \%$ of the articles.

Considering the approaches employed by researchers, the vast majority, $70 \%$ of the articles, utilised a qualitative approach. This approach focuses on the process and its meaning, so seeking to establish significance to the object under study. Only $8 \%$ of the articles used a quantitative approach, which guarantees data accuracy through the numerical and statistical analysis, largely avoiding distortions. Other researchers, i.e., $23 \%$ of the reviewed papers, use a mixed methods approach, which uses a combination of features from both qualitative and quantitative approaches (Creswell, 2003).

Regarding the research purpose categorisation, exploratory research, which is defined as the initial research that aims to provide greater familiarity with the problem in order to make it explicit or to build hypotheses, was represented in $57 \%$ of the leagile literature. Descriptive categorises a research that provides deeper information about a subject, aiming to describe characteristics and establish relationships between variables, it was seen in $47 \%$ of the articles. Explanatory research attempts to explain the reasons of a phenomena, in other words it aims to understand the cause and effect of an event (Yin, 2003), and occurs in only $9 \%$ of the texts.

The unit of analysis is the classification of the extension utilized by each author during the research. It describes how comprehensive or specific the studies were. The large majority of the articles have focused attention to supply chains $(70 \%)$, which is expected as this is where agility has considerable operational effectiveness. In Firm level investigations, (Company) constituted $15 \%$ of the articles reviewed. A focus on only the departmental level, made up $8 \%$ of all studies. Finally, product type category represented $4 \%$ of reviewed articles.

\subsubsection{Year}

The seminal paper by Naylor et al (1999) can be said to have begun the momentum of interest in leagile. This study (Naylor et al, 1999) focused on measuring the performance of leagile supply chains and developed ideas that still influence the study of this concept. Figure 1 shows the quantity and frequency of leagile articles published since Naylor et al's (1999) work first appeared.

Take in

Figure 1: Distribution of Articles since 1999 
From figure 1, the year that had the most publications on leagile was 2011 with seven articles, followed by 2006 and 2009 with six articles each. The years when there were fewest publications are 1999, 2002 and 2004 with only one article each. The study also shows that, within our defined research boundaries, no relevant papers at all were published in the years, 2003, 2005 or 2016.

\subsubsection{Journals}

Operations management journals with two or more publications with leagile as the focus of study are shown in Table 6 below.

Take in

Table 6: Journals with two or more core Leagile articles

Following data eollection thecollection the most targeted journals for leagile related output comprise: International Journal of Production Economics, International Journal of Production Research and Supply Chain Management: An International Journal. The number of papers published that are presented in Table 6 represents $43 \%$ of the total relevant articles found in this study.

\subsection{Contents and concepts}

This section reviews leagile/leagility content within articles. The concept itself, how each author explains it, the use of the words leagile and leagility, the terms that are used to define the concept, the theme that each paper addresses, the exploitation of small and medium enterprises and the sectors analysed.

\subsubsection{Definitions}

Table 7 compiles the key definitions stated in the articles.

Take in

Table 7: Definitions of leagile

Although, the majority of authors that developed an article in which leagile was the focus had cited Naylor et al. (1999) several authors combined concepts from different researchers and for this reason they are not acknowledged in Table 7 above: - Herer et al. (2002); Bruce et al. (2004); Bruce \& Daly (2006); Krishnamurthy \& Yauch, (2007); Hilletofth, (2009); Bruce \& Daly (2011); Soni \& Kodali (2012); Vinodh \& Aravindraj (2013); Birhanu et al. (2014); Gunawardhana et al. (2014); Purvis et al. (2014).

\subsubsection{Leagile, leagility and terminology}


The selected articles were reviewed in order to understand how the terms 'leagile' and leagility' had been used,.used. These findings are shown in Table 8 below where most of the papers (57\%) use both word terms, often interchangeably.

Take in

Table 8: Leagile vs leagility

A few papers made use of both words leagile and leagility, such as Childerhouse \& Towill (2000); Bruce et al. (2004); Agarwal et al. (2006); Nishat et al. (2006); Ambe \& Badenhorst-Weiss (2010); Banihashemi (2011); Bruce \& Daly (2011); Drake et al. (2013); Lemieux et al. (2015); and Olsson \& Aronsson (2015). Finally, most researchers (55\%) used leagility as a noun and leagile as an adjective, for example when referring to leagile supply chain, leagile technique, among others.

A variety of synonyms have been used with leagile/leagility. The most significant (by number of citations as reported by Google Scholar, April 2018) papers were as shown in Table 9. Articles were reviewed to see in which context, leagile was used. The results are noted in Table 10.

Take in

Table 9: Article vs terms

Take in

Table 10: Leagile context

\subsubsection{Themes}

Amongst all reviewed articles, the most common catagory appeared to be was supply chain and its divisions. Supply chain involves physical and non-physical functions (market-mediation function). The physical function covers the conversion of raw materials into parts, components and finished goods and the transport from one point of the supply chain to the next. The market mediation aims to ensure that the variety of products reaching the marketplace matches what consumers want to buy (Fisher, 1997). Thus, a supply chain involves the manufacturer, the suppliers, transportation, warehouses, retailers and customers and all activities involved to fulfil one customer demand (Galankashi et al., 2013).

Within the supply chain category, other subdivisions also emerge, such as supply chain management, supply chain strategies, supply networks as well as a combination of supply and demand chains. Supply chain management can be defined as "the integration of key business processes from end user through original suppliers that provides products, services, and information that adds value for customers and other stakeholders" (Lambert et al., 1998). Supply chain strategy helps an organization to use a specific 
strategy to determine the benefit of the operation, distribution, services and all its activities (Galankashi et al., 2013). The strategy determines how the supply chain should operate efficiently to compete (Karunaratne et al., 2012). There are two articles about supply networks that can be defined as "sets of supply chains, describing the flow of goods and services from original sources to end customers" (Harland, 1996). Additionally, Müller et al's (2009) investigation into supply and demand chains provides the definition as: "A demand chain is a supply chain that emphasizes market mediation to a greater degree than its role of ensuring efficient physical supply of the product". There are 34 articles $(66 \%)$. that explore the Supply Chain.

There are two articles for each of the following themes: Comparison of lean/agile (Christopher \& Towill, 2000; Olsson \& Aronsson, 2015), and Services (Rahimnia \& Moghadasian, 2010; Rahimnia et al., 2009). These articles compare both methodologies investigate their characteristics, their differences and their capability to consolidate leagile. The services focused area has two subdivisions, mass services and professional services in which leagility is applied. Mass services operations focus on products while professional services focus on process (Rahimnia \& Moghadasian, 2010).

The study and application of Leagile concepts into multiple areas has been continuing since the concepts inception, as exemplified by the following studies: Reverse Logistics Process (Banomyong et al., 2008), Application of leagility (Krishnamurthy \& Yauch, 2007), Construction (Demir et al., 2012), Decoupling Point (Liu et al., 2009), Mass customisation (Stump \& Badurdeen, 2012), - early Concept (Van Hoek, 2000), Operational Strategy (Guimarães \& de Carvalho, 2012), Performance optimisation (Chan et al., 2009), Product Development (Lemieux et al., 2015), Production System (Court et al., 2006), Purchasing portfolio model (Drake et al., 2013), Remove Non Value Activities (Chen et al., 2015), Value Networks (Gunawardhana et al., 2014).

\subsubsection{Small and medium-size enterprises}

The small and medium-size enterprises (SME) have a significant impact in the economy and comprise a big part of industry. In the European Union, 78\% of all companies are SMEs and they are responsible for 58 cents in each euro of value added of equivalent net contribution that comes from the companies to the economy (Ec.europa.eu, 2015).

Even though SMEs should work hard to keep up and compete in market, they are less likely to implement methodologies such as lean manufacturing that are used by the bigger companies. And reflecting that reality, there are only a few researches about implementation of those kind of techniques when SMEs are involved (Bakas et al., 2011).

Considering these points, an effort was made to find out how many scientific leagile focused publications address the issue of SMEs. Among all the articles found about leagile/leagility, only 5 dealt with SMEs, equivalent to $9 \%$ of the total. These papers being: Nishat et al., 2006; Krishnamurthy \& Yauch, 2007; Huang \& Li, 2010; Galankashi et al., 2013; and Ramana et al., 2013.

\subsubsection{Industry Sectors}

Industry sectors investigated by researchers are listed in Table 11 below. The Apparel and Textile Industry has been the sector where most of the attention has been focused. This sector is generally known to be one of the major sectors in both industrialised and developing countries contributing significantly to employment and revenue (Bruce et al, 2004). The sector is also known to operate in a rather volatile environment with short product life cycles and high product variety hence 
adoption of lean and agile strategies are viewed important for the company's success and continuation These conditions probably lend reasons as to why this sector has been popular in studies.

Take in

Table 11: Industry Sectors

\section{Discussion and conclusions}

Although leagile is a subject that has been studied since the late 1990s, it has not been as intensely investigated as the Lean concept itself, in their work, Jasti \& Kodali (2015) discovered 546 articles on lean alone. With reference to Table 3, relevant articles, almost half of the total number of papers were irrelevant to this investigation on leagile, where articles only dealt with leagile in superficial or elementary terms. As leagile is viewed as critical in enhancing excellence in total quality management and manufacturing and supply chain performance, it is somewhat surprising that more focus has not been brought to bear to this field, as an advancement to standard lean theory and operations alone.

Although there is continuing interest in Leagile as a study, publications of good quality and research that may progress the field are observed to be in a decline. There are a few recent articles to be found that have a core Leagile focus, and unfortunatley, these are collectively very poor and not published in strong management journals. Instead, they have been published in provincial conferences and low quality, obscure publications. With regard to the rate of article output, it is noticeable that there is a clear decline in the work on leagile. The importance of the leagile topic can also be recognised by the fact that $32 \%$ of articles have been published in strong, international journals of high impact (see table 6) such as International Journal of Operations and Production Management, International Journal of Production Economics, International Journal of Production Research, Production Planning \& Control and Supply Chain Management: An International Journal.

In the categories 'unit of analysis', 'theme' and 'term', it was verified that all articles discuss supply chain and it is predominant in the three topics. In the unit of analysis, $69 \%$ of the articles discuss about supply chain, $66 \%$ of papers have this subject as the theme and $34 \%$ of articles refer to leagile as a kind of supply chain. This is because the most important thing for a company is to satisfy customer needs and configuring the supply chain in the right way is a good start to achieve this requirement. With the integration of lean and agile methodologies, it is possible to facilitate the transport of materials, money, resources and information, improving the supply chain depending on the type of product and meeting market demand. These characteristics demonstrate that different researchers agreed and there is a consensus on these issues in the leagile literature.

It was also found that most researchers used leagile and leagility, but sometimes interchangeably. In conclusion, most authors used leagile as an adjective, in order to qualify something, such as leagile supply chain, and leagility was mainly used as a noun.

With regards to small and medium-size enterprises, the current number of publications is substantially low, with only $10 \%$ of the total. From a research perspective this is quite insufficient 
since SMEs have a great impact in the economy. Research on SMEs therefore, requirestherefore, requires special attention in order to be able to compete with bigger companies and also with other SMEs since they do not have many barriers to get in the market.

\subsection{Research methodologies}

Regarding the methodological approach, $73 \%$ of research articles have used a qualitative approach which although providing rich and deep understanding, may also give rise to some subjective weakness through specifics of application. The counter argument to this is that through the use of quantitative methods, numerically more objective, these publications have tended to exhibit a shortage of explanatory research. It was found that $36 \%$ of all articles made use of a case study methodology, with only half focusing on a specific industry sector. Fundamentally, the research methods must of course reflect the research enquiry objectives and we discover that the majority of research studies have focused on supply chains, using cases to explore and describe in order to build theory. We can now reflect on whether complimentary research methods would add to our understanding of the leagile phenomenon. For example, studies research using quantitative approaches that look at the growing service, retail or healthcare sectors would be valuable additions to the field.

\subsection{Research purpose}

This study has used definitions of research purpose taken from Robson (2002) where, 'Exploratory' seeks to determine what is happening, 'Descriptive' seeks to describe/profile situations and where 'Explanatory' seeks to show how variables are related. This research finds that only $8 \%$ of the relevant articles could be classified as having conducted explanatory research. Having recognised this outcome, even works such as Chan et al (2015) that engage with explanatory schemes, the leagile content can become lost in the application of research tools, in this case, algorithm/simulation. Our findings strongly indicate that there is a lack of research pursuing (and therefore a research gap) in using explanatory research and so posing opportunities for researchers interested in pursuing a 'path less travelled' and of advancing academic and practitioner value.

\subsection{Leagile performance}

Based on the literature review findings, leagile strategies have long been recognised by various industry sectors as useful, particularly so in manufacturing. This recognition and recent increase of research in the area, particularly service sectors such as healthcare, suggests that the adoption of leagile practices and initiatives significantly influence business performance. The traditional approach would be to look at case studies in specific industries to explore how leagile strategies are adopted and evolves depending on changing market situations and to determine whether there is a difference in the way leagile strategy works in different industry settings and contexts. This approach provides deeper insights and enables learning especially for SMEs that are considering adoption of leagile strategies. A good example of this is the study conducted by Kisperska-Moron and De Haan (2011) on fast moving consumer goods sector in Poland where they observed varying degrees of lean and agile applications as market changes occured. Many industries today both mature and upcoming are also required by the various regulatory bodies in which they operate in to carry out more transparent and stringent reporting consequently, enabling researchers to capture objective information to complement existing methods for a more comprehensive understanding. Improvements in reporting can enable 
researchers to ascertain leagile related performance for companies. The study by Malmbrandt and Åhlström (2013) for instance offers useful instruments for capturing performance measures on lean production and adoption for companies.

\subsection{Sectoral focus}

Based on the this review, the adoption of leagile strategies and work done to date seems to be mainly isolated to manufacturing (specifically, apparel and electronics). This makes sense as lean applications were born out of manufacturing (i.e., origins in the Toyota Production System) and gradually adopted in a beyond automotive by firms in other industries More in-depth studies of firms nested in this sector could offer a greater understanding of why adoption is apparently easier and feasible in manufacturing. Research in the service sector has been limited and with an increasing interest in healthcare, there is an opportunity for researchers to explore this sector along with others given that today, many firms consider themselves as providing a bundle of benefits. This will give some insights into how leagile strategies can be promising in shaping business performance and successes. While the concept of leagile may be universally understood, there are differences in measures adopted and cost benefits in various industries hence requires more studies to be done. Different degrees of lean and agile implementations in service supply chains and contexts are also suggested. For instance, Arlbjørn et al (2011) studied lean implementation in Danish municipalities using a mixture of surveys and case studies. Through their findings they offered a model that illustrated conditions where lean is seen as appropriate depending on the type of service provided. There is potential for application of lean for organisations operating in the public sector. Their study acknowledges lean philosophy and advocates the need for in-depth research in these sectors.

\subsection{Further research}

Although the characteristics of a leagile supply chain strategy is known, it is necessary that more practical studies be made by comparing the paradigms lean, agile and leagile, to better understand the difficulties and good implementation practices of the theme. In addition to tests with the three different paradigms, theparadigms, the application of the leagile hybrid approaches (decoupling point, Pareto curve, surge and base demands) should be considered. Since each one should be used for different situations, there is scope for more studies about their characteristics and possibilities.

For researchers, further study should be undertaken in a wide variety of industries sizes and types, therefore extending and increasing the comprehension of leagile in different sectors. The leagile subject should be studied specially in services, exploring more mass and professional services and also other areas within these categories. Firms operating within the public sector should not be ignored. The health sector is a particularly fitting sector which has seen recent developments in improvements along the lines of lean and agile. Given the competitive and progressive nature of this industry and mandatory requirements by the state and health bodies, there is a wealth of information that is publicly available for researchers.

Furthermore, given that there is general agreement and consensus on the 'leagile' concept, future researchers can take a more rigorous approach by identifying suitable proxy measures on leanness, agility, leagile terms and collecting more objective data for the purposes of empirical testing. This approach will give more latitude in understanding how leagile is implemented and practiced in 
service and manufacturing organisations and highlight the factors that may promote stronger performance. Despite the richness gained from case studies, a mixed method could be more insightful.

Small and medium-size enterprises have a significant share of the market and are important actors in the economy. This subject should be more explored because the current number of papers is relatively low with only $10 \%$. In this regard, studies should be done aiming to develop a route map to implement leagility in SMEs and also to establish good practices for those companies. Other interesting lines of research would be the comparisons between the implementation of leagile in SME and large companies and the difficulties each of them faces as well as the differences in perception, pressures and incentives for the adoption of leagile activities. In summary, there are numerous opportunities for future research that this study has found, and the most immediate include:

- Comparison of the lean-related paradigms

- Research of leagile in the service sector

- Research of leagile application in healthcare

- Understanding of practical leagile measures and cost benefits

- Focus on leagile with the SME sector

- Possible application of quantitative methods and approaches to leagile systems understanding

We anticipate that our recommendations will provide direction to future researchers to undertake more rigorous work in this area. Regarding limitations, this study has been selective with the papers that we have included as relevant for the purposes of analysis and therefore disregarded works such as conference papers, doctoral dissertations, textbooks and book chapters. Based on the relevant articles, we were able to categorise and identify the themes that have emerged over the time period and offered suggestions based on analysis. Future studies can make more impactful research by exploring individual themes in less researched industries along the methodologies suggested. In particular, how leagile practices could be further developed or influenced by technologies such as Industry 4.0 and vulnerabilities and risks as associated with the broad theme of resilience and security.

\section{References}

Agarwal, A., Shankar, R., \& Tiwari, M. K. (2006). Modelling the metrics of lean, agile and leagile supply chain: An ANPbased approach. European Journal of Operational Research, 173(1), 211-225.

Ahmed, W. \& Huma, S. (2018) Impact of lean and agile strategies on supply chain risk management, Total Quality Management \& Business Excellence, DOI: 10.1080/14783363.2018.1529558.

Aitken, J.; Christopher, M.; Towill, D. (2002). Understanding, implementing and exploiting agility and leanness. International Journal of Logistics, 5(1), pp. 59-74.

Akyuz, G.K. (2015) Quality excellence in complex supply networks: EFQM excellence model reconsidered, Total Quality Management \& Business Excellence, 26:11-12, 1282-1297.

Ambe, I. M. (2014) Differentiating supply chain strategies: the case of light vehicle manufacturers in South Africa. Problems and Perspectives in Management, 12(4), 415-426.

Ambe, I. M., \& Badenhorst-Weiss, J. A. (2010). Strategic supply chain framework for the automotive industry. African Journal of Business Management, 4(10), 2110-2120. 
Anand, G., \& Kodali, R. (2008). A conceptual framework for lean supply chain and its implementation. International Journal of Value Chain Management, 2(3), 313-357.

Anvari, A., Zulkifli, N., \& Yusuff, R. M. (2013). A dynamic modelling to measure lean performance within lean attributes. The International Journal of Advanced Manufacturing Technology, 66(5-8), 663-677.

Arlbjørn, J.S., Freytag, P.V., de Haas, H. (2011) "Service supply chain management: A survey of lean application in the municipal sector", International Journal of Physical Distribution \& Logistics Management, Vol. 41 Issue: 3, pp.277-295.

Bakas, O., Govaert, T., \& Van Landeghem, H. (2011). Challenges and success factors for implementation of lean manufacturing in European SMES. In 13th International Conference on the Modern Information Technology in the Innovation Processes of the Industrial Enterprise. Tondheim, Norway, NTNU Engineering Series (Vol. 1).

Baker, P. (2008). The design and operation of distribution centres within agile supply chains. International Journal of Production Economics, 111(1), 27-41.

Banerjee, A. (2014). Information technology enabled process re-engineering for supply chain leagility. International Journal of Information Technology and Management, 14(1), 60-75.

Banerjee, A., Sarkar, B., \& Mukhopadhyay, S. K. (2012). Multiple decoupling point paradigms in a global supply chain syndrome: a relational analysis. International Journal of Production Research, 50(11), 3051-3065.

Banihashemi, S. A. (2011). Improving supply chain performance: The strategic integration of lean and agile supply chain. African Journal of Business Management, 5(17), 7557-7563.

Banomyong, R., Veerakachen, V., \& Supatn, N. (2008). Implementing leagility in reverse logistics channels. International Journal of Logistics: Research and Applications, 11(1), 31-47.

Bastos, J., Almeida, A., Azevedo, A., \& Ávila, P. (2012). A Flexibility Reference Model to Achieve Leagility in Virtual Organizations. In Virtual and Networked Organizations, Emergent Technologies and Tools, 196-206.

Bhamra, R., Dani, S., \& Burnard, K. (2011). Resilience: the concept, a literature review and future directions. International Journal of Production Research, 49(18), 5375-5393.

Bicheno, J.; Holweg, M. (2004). The new lean toolbox. Traduction. Buckingham: PICSIE Books.

Birhanu, D., Lanka, K., \& Rao, A. N. (2014). A Survey of Classifications in Supply Chain Strategies. Procedia Engineering, 97(1), 2289-2297.

Borgström, B., \& Hertz, S. (2011). Supply Chain Strategies: Changes in Customer Order-Based Production. Journal of Business Logistics, 32(4), 361-373.

Boschi, A. A., Borin, R., \& Batocchio, A. (2011). Leagile-The New Framework for the Supply Chain Management. In IIE Annual Conference. Proceedings (p. 1). Institute of Industrial Engineers-Publisher.

Bruce, M., \& Daly, L. (2006). Buyer behaviour for fast fashion. Journal of Fashion Marketing and Management: An International Journal, 10(3), 329-344.

Bruce, M., \& Daly, L. (2011). Adding value: challenges for UK apparel supply chain management-a review. Production Planning \& Control, 22(3), 210-220.

Bruce, M., Daly, L., \& Towers, N. (2004). Lean or agile: a solution for supply chain management in the textiles and clothing industry? International journal of operations \& production management, 24(2), 151-170.

Cai, Y., \& Zhu, D. (2013). A Theoretical Exploration for Supply Chain Leagility Capability. In System Sciences (HICSS), 2013 46th Hawaii International Conference on (pp. 4126-4135).

Chan, F. T., \& Kumar, V. (2009). Performance optimization of a leagility inspired supply chain model: a CFGTSA algorithm-based approach. International Journal of Production Research, 47(3), 777-799. 
Chan, F. T., Kumar, V., \& Tiwari, M. K. (2009). The relevance of outsourcing and leagile strategies in performance optimization of an integrated process planning and scheduling model. International Journal of Production Research, 47(1), $119-142$.

Chan, J. W., \& Burns, N. D. (2002). Benchmarking manufacturing planning and control (MPC) systems: an empirical study of Hong Kong supply chains. Benchmarking: An International Journal, 9(3), 256-277.

Chartered Association of Business Schools, (2015). Academic Journal Guide 2015 - Chartered Association of Business Schools. [online] Available at: http://charteredabs.org/academic-journal-guide-2015/ [Accessed 10 Aug. 2015].

Chen, P. S., Yu, C. J., \& Chen, G. Y. H. (2015). Applying Task-Technology Fit Model to the Healthcare Sector: a Case Study of Hospitals' Computed Tomography Patient-Referral Mechanism. Journal of medical systems, 39(8), 1-14.

Childerhouse, P., \& Towill, D. (2000). Engineering supply chains to match customer requirements. Logistics information management, 13(6), 337-346.

Christiansen, P. E., Kotzab, H., \& Mikkola, J. H. (2007). Coordination and sharing logistics information in leagile supply chains. International Journal of Procurement Management, 1(1-2), 79-96.

Christopher, M. C. (2000). The agile supply chain: competing in volatile markets. Industrial Marketing Management, 29(1), 37-44.

Christopher, M., \& Ryals, L. J. (2014). The supply chain becomes the demand chain. Journal of Business Logistics, 35(1), 29-35.

Christopher, M., \& Towill, D. R. (2000). Supply chain migration from lean and functional to agile and customised. Supply Chain Management: An International Journal, 5(4), 206-213.

Corley, K. G., \& Gioia, D. A. (2011). Building theory about theory building: what constitutes a theoretical contribution? Academy of Management Review, 36(1), 12-32.

Costa, L.B.M. \& Filho, M.G., (2016). Lean healthcare: review, classification and analysis of literature. Production Planning \& Control, Vol. 27 (10).

Court, P., Pasquire, C., Gibb, A., \& Bower, D. (2006). Design of a lean and agile construction system for a large and complex mechanical and electrical project. In Proc., Fourteenth Annual Conf. of the Int. Group for Lean Construction (IGLC-14) (pp. 151-164).

Creswell, J. (2003). Research design. Thousand Oaks, Calif.: Sage Publications.

Demir, S. T., Bryde, D. J., Fearon, D. J., \& Ochieng, E. G. (2012). Re-conceptualising agile for lean construction: The case for" agilean" project management. In Procs 28th Annual ARCOM Conference (pp. 3-5).

Drake, P. R., Myung Lee, D., \& Hussain, M. (2013). The lean and agile purchasing portfolio model. Supply Chain Management: An International Journal, 18(1), 3-20.

Eaton, M. (2003). Running the leagile marathon [lean/agile improvement programmes]. Manufacturing Engineer, 82(6), 14-17.

Ec.europa.eu, (2015). European Commission. [online] Available at: http://ec.europa.eu/index_en.htm [Accessed 3 Aug. 2017].

Eisenhardt, K. M. (1989). Building theories from case study research. Academy of management review, 14(4), 532-550.

Eriksson, D., \& Hedenstierna, C. P. T. (2012). Matching supply chain strategy with business strategy and the results of a mismatch. International Journal of Manufacturing Research, 7(2), 181-197.

Fisher, M. L. (1997). What is the right supply chain for your product? Harvard business review, 75(1), 105-117.

Galankashi, M. R., Ziaei, F., Helmi, S. A., \& Baniani, A. M. (2013). Assessment of Supply Chain Strategies and Analysis on the Performance of Companies Deployed Strategy Using Activity Based Approach. Journal Technology, 64(2), 39-43. 
Goldsby, T. J., Griffis, S. E., \& Roath, A. S. (2006). Modelling lean, agile, and leagile supply chain strategies. Journal of business logistics, 27(1), 57-80.

Guimarães, C. M., \& de Carvalho, J. C. (2012). Outsourcing in Healthcare Through Process Modularization-A Lean Perspective. International Journal of Engineering Business Management, 4(1), 1-12.

Gunawardhana, N., Suzuki, S., \& Enkawa, T. (2014). Supply Chain Management with Leanness and Agility: A Value Network Perspective with a B2B Apparel Case Study. Journal of Japan Industrial Management Association, 64(4E), 591600 .

Gupta, S., Garg, M., Goh, M., \& Kumar, M. (2009). Leagility in Manufacturing and Procurement: A Conceptual Framework. Always-On Enterprise Information Systems for Business Continuance: Technologies for Reliable and Scalable Operations: Technologies for Reliable and Scalable Operations, 175.

Guven-Uslu, P., Chan, H. K., Ijaz, S., Bak, O., Whitlow, B., \& Kumar, V. (2014). In-depth study of 'decoupling point' as a reference model: an application for health service supply chain. Production Planning \& Control, 25(13-14), 1107-1117.

Hallgren, M.; Olhager, J. (2009). Lean and agile manufacturing: external and internal drivers and performance outcomes. International Journal of Operations \& Production Management, 29(10), pp. 976-999.

Harland, C. M. (1996). Supply chain management: relationships, chains and networks. British Journal of management, $7(1), 63-80$.

Herer, Y. T., Tzur, M., \& Yücesan, E. (2002). Transhipments: An emerging inventory recourse to achieve supply chain leagility. International Journal of production economics, 80(3), 201-212.

Heydari, J. (2011). Paradigms of Supply Chain Management. Supply Chain Sustainability and Raw Material Management: Concepts and Processes, 149.

Hilletofth, P. (2009). How to develop a differentiated supply chain strategy. Industrial Management \& Data Systems, 109(1), 16-33.

Ho, W., Zheng, T., Yildiz, H. \& Talluri, S., (2015). Supply chain risk management: a literature review. International Journal of Production Research, 53(16), 5031-5069.

Huang, Y. Y., \& Li, S. J. (2010). How to achieve leagility: A case study of a personal computer original equipment manufacturer in Taiwan. Journal of Manufacturing Systems, 29(2), 63-70.

Inman, R. A., Sale, R. S., Green, K. W., \& Whitten, D. (2011). Agile manufacturing: relation to JIT, operational performance and firm performance. Journal of Operations Management, 29(4), 343-355.

Jin-Hai, L.; Anderson, A.; Harrison, R. (2003). The evolution of agile manufacturing. Business Process Management Journal, 9(2), pp. 170-189.

Jia, H. M., Yu, K. C., \& Zhang, J. C. (2014). A Study on Leagile Supply Chain Model and Performance Evaluation System Based on Lean Agile Theory. Applied Mechanics and Materials, 635(1), 1771-1775.

Jasti, N. V. K. \& Kodali, R., (2015). Lean production: literature review and trends. International Journal of Production Research, 53(3), 867-885.

Karunaratne, A., Chi, L. M., Min, H. S., \& Sorooshian, S. (2012). Supply chain strategy. International Journal of Innovative Ideas, 12(4), 7-8.

Katayama, H.; Bennett, D. (1999). Agility, adaptability and leanness: a comparison of concepts and a study of practice. International Journal of Production Economics, 60-61, pp. 43-51.

Kidd, P. (1994). Agile manufacturing. Traduction. Wokingham, England: Addison-Wesley.

Kisperska-Moron, D., \& De Haan, J. (2011). Improving supply chain performance to satisfy final customers: "Leagile" experiences of a polish distributor. International Journal of Production Economics, 133(1), 127-134. 
Krishnamurthy, R. (2004). Defining the Boundaries of a Corporate Leagile Infrastructure. In IIE Annual Conference. Proceedings (p. 1). Institute of Industrial Engineers.

Krishnamurthy, R., \& Yauch, C. A. (2007). Leagile manufacturing: a proposed corporate infrastructure. International Journal of Operations \& Production Management, 27(6), 588-604.

Kumar, V., Maull, R. S., Smart, P. A., \& Tiwari, M. K. (2006). Artificial Immune System (AIS) based information system to solve scheduling problem in leagile driven steel industries. In Digital Information Management, 2006 1st International Conference on (pp. 373-380).

Lambert, D. M., Cooper, M. C., Pagh, J. D., (1998). Supply chain management: implementation issues and research opportunities. International Journal of Logistics Management, 9(2), 1-19.

Larsson, J., Peterson, J., \& Mattila, H. (2012). The knit on demand supply chain. Autex Research Journal, 12(3), 67-75.

Lemieux, A. A., Lamouri, S., Pellerin, R., \& Tamayo, S. (2015). Development of a leagile transformation methodology for product development. Business Process Management Journal, 21(4), 791-819.

Li, X., Mao, Z., Xia, G., \& Jia, F. (2008). Study on Manufacturing Supply Chain Leagile Strategy Driven Factors Based on Customer Value. Wireless Communications, Networking and Mobile Computing, 2008. WiCOM'08. 4th International Conference on (pp. 1-4).

Li, Z. F., Zhang, R., \& Xue, X. L. (2004). Leagile supply chain strategy in housing industry facing the customer satisfaction. Journal of Harbin Institute of Technology, 10, 036.

Liu, D., Wang, W., \& Fu, W. (2009). CODP position of leagile supply chain based on polychromatic sets theory. In Automation and Logistics, 2009. ICAL'09. IEEE International Conference on (pp. 432-437).

Mao, Z., Xiaomei, L., Ershi, Q., \& Fu, J. (2009). Research on supply strategy driven factors of SDN based on product and service characteristics. In Service Operations, Logistics and Informatics, 2009. SOLI'09. IEEE/INFORMS International Conference on (pp. 713-717).

Malmbrandt, M. \& Åhlström, P. (2013). An instrument for assessing lean service adoption. International Journal of Operations \& Production Management, Volume: 33 Issue: 9.

Mason-Jones, R., Naylor, B., \& Towill, D. R. (2000a). Engineering the leagile supply chain. International Journal of Agile Management Systems, 2(1), 54-61.

Mason-Jones, R., Naylor, B., \& Towill, D. R. (2000b). Lean, agile or leagile? Matching your supply chain to the marketplace. International Journal of Production Research, 38(17), 4061-4070.

Matawale, C. R., Datta, S., \& Mahapatra, S. S. (2013). Interrelationship of capabilities/enablers for lean, agile and leagile manufacturing: an ISM approach. International Journal of Process Management and Benchmarking, 3(3), 290-313.

Mathiyazhagan, T., \& Nandan, D. (2010). Survey Research Method, 34-82.

Mishra, V., Samuel, C. \& Sharma, S.K. (2018) Lean, agile and leagile healthcare management - A case of chronic care, International Journal of Healthcare Management, Published online: 26 Jan 2018.

Müller, E., Nikoghosyan, N., Rutsch, A., \& Schumann, C. A. (2009). Assessing supply and demand chain leagility according to Hooke's law for a single-agent scenario. In Industrial Engineering and Engineering Management, 2009. IEEM 2009. IEEE International Conference on (pp. 1411-1413).

Mutingi, M., (2013). Integrating lean and agile manufacturing paradigms: a dynamic simulation analysis, International Journal of Agile Systems and Management, Vol.6, No.4, pp.391 - 402.

Naim, M. M., \& Gosling, J. (2011). On leanness, agility and leagile supply chains. International Journal of Production Economics, 131(1), 342-354.

Naylor, J. B., Naim, M. M., \& Berry, D. (1999). Leagility: integrating the lean and agile manufacturing paradigms in the total supply chain. International Journal of production economics, 62(1), 107-118. 
Negrao, L.L.L., Filho, M.G. \& Marodin, G., (2017). Lean practices and their effect on performance: a literature review, Production Planning \& Control, Vol. 28 (1).

Nieuwenhuis, P., \& Katsifou, E. (2015). More sustainable automotive production through understanding decoupling points in leagile manufacturing. Journal of Cleaner Production, 95, 232-241.

Nishat F., M., Banwet, D. K., \& Shankar, R. (2006). Mapping supply chains on risk and customer sensitivity dimensions. Industrial Management \& Data Systems, 106(6), 878-895.

Noskievicova, D. (2013). Capability analysis for Leagile manufacturing processes. In Carpathian Control Conference (ICCC), 2013 14th International (pp. 262-266).

Ohno, T. (1988). Toyota Production Systems: Beyond Large Scale Production, Productivity Press, Cambridge, MA.

Olsson, O., \& Aronsson, H. (2015). Managing a variable acute patient flow-categorising the strategies. Supply Chain Management: An International Journal, 20(2), 113-127.

Owen, R., Koskela, L. J., Henrich, G., \& Codinhoto, R. (2006). Is agile project management applicable to construction? In Proceedings of the 14th Annual Conference of the International Group for Lean Construction (pp. 51-66).

Pai, M., McCulloch, M., Enanoria, W., \& Colford, J. M. (2004). Systematic reviews of diagnostic test evaluations: what's behind the scenes? Evidence Based Medicine, 9(4), 101-103.

Ponticelli, S., Mininno, V., Dulmin, R., \& Aloini, D. (2013). Supply chain implications for one-off luxury products: cases from the yacht industry. International Journal of Retail \& Distribution Management, 41(11/12), 1008-1029.

Purvis, L., Gosling, J., \& Naim, M. M. (2014). The development of a lean, agile and leagile supply network taxonomy based on differing types of flexibility. International Journal of Production Economics, 151(1), 100-111.

Qi, F., Xuejun, X., \& Zhiyong, G. (2007). Research on Lean, Agile and Leagile supply chain. In Wireless Communications, Networking and Mobile Computing, 2007. WiCom 2007. International Conference on (pp. 4902-4905).

Rahimnia, F., \& Moghadasian, M. (2010). Supply chain leagility in professional services: how to apply decoupling point concept in healthcare delivery system. Supply Chain Management: An International Journal, 15(1), 80-91.

Rahimnia, F., Moghadasian, M., \& Castka, P. (2009). Benchmarking leagility in mass services: The case of a fast food restaurant chains in Iran. Benchmarking: An International Journal, 16(6), 799-816.

Ramana, D., Rao, K., \& Kumar, J. (2013). Evaluation of performance metrics of leagile supply chain through fuzzy MCDM. Decision Science Letters, 2(3), 211-222.

Robson, C. (2002). Real World Research: A Resource for Social Scientists and Practitioner-Researchers, Wiley.

Rowley, J., \& Slack, F. (2004). Conducting a literature review. Management Research News, 27(6), 31-39.

Scholz-Reiter, B., \& Mehrsai, A. (2010). Superior performance of Leagile supply networks by application of autonomous control. In Advances in production management systems. New challenges, new approaches (pp. 333-341).

Shahin, A., \& Jaberi, R. (2011). Designing an integrative model of leagile production and analyzing its influence on the quality of auto parts based on Six Sigma approach with a case study in a manufacturing company. International journal of lean six sigma, 2(3), 215-240.

Shukla, S. K., \& Wan, H. D. (2010). A leagile inventory-location model: formulation and its optimisation. International Journal of Operational Research, 8(2), 150-173.

Soni, G., \& Kodali, R. (2009). Performance value analysis for the justification of the leagile supply chain. International Journal of Business Performance Management, 11(1-2), 96-133.

Soni, G., \& Kodali, R. (2012). Evaluating reliability and validity of lean, agile and leagile supply chain constructs in Indian manufacturing industry. Production Planning \& Control, 23(10-11), 864-884.

Stavrulaki, E., \& Davis, M. (2010). Aligning products with supply chain processes and strategy. The International Journal of Logistics Management, 21(1), 127-151. 
Stump, B., \& Badurdeen, F. (2012). Integrating lean and other strategies for mass customization manufacturing: a case study. Journal of Intelligent manufacturing, 23(1), 109-124.

Subramanian, N., \& Rahman, S. (2014). Supply chain complexity and strategy. In Supply Chain Strategies, Issues and Models (pp. 1-27).

Sugimori, Y., Kusunoki, K., Cho, F., \& Uchikawa, S. (1977). Toyota production system and kanban system materialization of just-in-time and respect-for-human system. The International Journal of Production Research, 15(6), 553-564.

Taylor, G. D., Love, D. M., Weaver, M. W., \& Stone, J. (2008). Determining inventory service support levels in multinational companies. International Journal of Production Economics, 116(1), 1-11.

van der Vorst, J. G., Dijk, S. J. V., \& Beulens, A. J. (2001). Supply chain design in the food industry. The International Journal of Logistics Management, 12(2), 73-86.

Van Hoek, R. I. (2000). The thesis of leagility revisited. International Journal of Agile Management Systems, 2(3), 196201.

Vinodh, S., \& Aravindraj, S. (2013). Evaluation of leagility in supply chains using fuzzy logic approach. International Journal of Production Research, 51(4), 1186-1195.

Vinodh, S., \& Aravindraj, S. A. (2012). Determination of Leagile Supply Chain Index Using Fuzzy ANP Approach. Advanced Materials Research, 488(1), 1614-1618.

Wang, X., Conboy, K., \& Cawley, O. (2012). "Leagile" software development: An experience report analysis of the application of lean approaches in agile software development. Journal of Systems and Software, 85(6), 1287-1299.

Wang, Y. (2011). Research on Main Characteristics and Application of Manufacturing Legal Supply Chain. In Information Management, Innovation Management and Industrial Engineering (ICIII), 2011 International Conference on (Vol. 2, pp. 538-542).

Wee, H. M., \& Yang, P. C. (2007). A mutual beneficial pricing strategy of an integrated vendor-buyers inventory system. The International Journal of Advanced Manufacturing Technology, 34(1-2), 179-187.

Wikner, J. (2014). Supply Chain Management Strategies in Terms of Decoupling Points and Decoupling Zones. In Advances in Production Management Systems. Innovative and Knowledge-Based Production Management in a GlobalLocal World (pp. 371-378).

Womack, J.P, Jones, D.T. and Roos, D. The Machine that Changed the World, Rawson Associates, New York, 1990.

Womack, J. P.; Jones, D. T. (1994). From lean production to lean enterprise. Harvard business review, 72(2), pp. 93-103.

Womack, J. P.; Jones, D. T. (1996). Lean thinking. . New York: Free Press.

Yin, R. (2003). Case study research. Thousand Oaks, Calif.: Sage Publications.

Yusuf, Y.; Sarhadi, M.; Gunasekaran, A. (1999). Agile manufacturing: the drivers, concepts and attributes. International Journal of Production Economics, 62(1), pp. 33-43.

Zhang, M., \& Qi, Y. (2013). Impact of supply chain strategy on mass customisation implementation and effectiveness: evidence from China. International Journal of Information and Decision Sciences, 5(4), 393-413. 